\title{
What Is the Best End Use for Compost Derived from the Organic Fraction of Municipal Solid Waste?
}

\author{
Mojtaba Sardarmehni, James W. Levis*, Morton A. Barlaz \\ Department of Civil, Construction, and Environmental Engineering, North Carolina State \\ University, Raleigh, North Carolina 27695-7908 \\ * Corresponding author. Phone: (919) 515-7823; Fax: (919) 515-7908; Email: jwlevis@ncsu.edu
}

\section{Supporting Information}

Number of pages: 21

Number of tables: 8

Number of figures: 17

Number of equations: 27 


\section{Mathematical model}

All the parameters used in equations S1 to S27 are described in Tables 1 and 2.

Carbon balance in soil amendment scenario:

$$
\begin{aligned}
& \mathrm{CO}_{2_{\text {Stor }}}=\left(1-\text { Comp }_{\text {Moist.Cont }}\right) \times C_{C} \times C_{\text {Stor.c }} \times \frac{44}{12} \\
& \mathrm{CO}_{2_{\text {Emit }}}=\left(1-\text { Comp }_{\text {Moist.Cont }}\right) \times C_{c} \times\left(1-C_{\text {Stor.c }}\right) \times \frac{44}{12}
\end{aligned}
$$

Carbon balance in alternative daily cover (ADC) scenario:

$$
\begin{aligned}
& \mathrm{CO}_{2_{\text {Stor-LF }}}=\left(1-\text { Comp }_{\text {Moist.Cont }}\right) \times C_{c} \times C_{\text {Stor }}+\frac{44}{12} \\
& \mathrm{CH}_{4 \text { Prod }}=\left(1-\text { Comp }_{\text {Moist.Cont }}\right) \times C_{c} \times\left(1-C_{\text {Stor }_{L F}}\right) \times C_{\text {frac.C4 }} \times 16 / 12 \\
& \mathrm{CH}_{4_{\text {Emit }}}=\mathrm{CH}_{4_{\text {Prod }}} \times\left(1-\mathrm{CH}_{4 \text { Col }}\right) \times\left(1-\mathrm{CH}_{4 O X}\right) \\
& \mathrm{CH}_{4_{\text {Eng.rec }}}=\mathrm{CH}_{4_{\text {Prod }}} \times \mathrm{CH}_{4 \text { Col }} \times\left(1-\mathrm{CH}_{4_{\text {Flr }}}\right) \\
& \text { Elec }\left(k W h_{\text {elec }}\right)=C H_{4_{\text {Eng.rec }}} \times L H V_{C 4}\left(\frac{M J}{k g}\right) \times \text { Elec }_{\text {eff }} \times \frac{1}{3.6} \times \operatorname{Grid}_{\text {mix }} \\
& \mathrm{CO}_{2_{\text {Emit }-L F}}=\left(1-\text { Comp }_{\text {Moist.Cont }}\right) \times C_{c} \times\left(1-C_{\text {Stor }}\right) \times\left(1-C_{\text {frac.C4 }}\right) \times \frac{44}{12} \\
& +\mathrm{CH}_{4 \text { Prod }} \times\left(\mathrm{CH}_{4 \mathrm{Col}}+\left(1-\mathrm{CH}_{4 \mathrm{Col}}\right) \mathrm{CH}_{4}{ }_{\mathrm{Ox}}\right) \times \frac{44}{16}
\end{aligned}
$$

Nutrient balance in soil amendment scenario:

$$
\begin{aligned}
& \mathrm{NH}_{3_{\text {Emit }}}=\left(1-\text { Comp }_{\text {Moist.Cont }}\right) \times N_{c} \times N_{\text {farc. } \mathrm{NH}_{3}} \times \mathrm{NH}_{3} \text { frac.evap } \\
& \mathrm{N}_{2} \mathrm{O}_{\text {Emit }}=\left(1-\text { Comp }_{\text {Moist.Cont }}\right) \times N_{c} \times N_{\text {frac. } \mathrm{N}_{2} \mathrm{O}} \\
& \mathrm{NO}_{3_{G_{-} W t r}}=\left(1-\text { Comp }_{\text {Moist.Cont }}\right) \times N_{c} \times N_{{\text {frac. } N O_{3}}_{3}} \times \text { frac }_{G W} \\
& \mathrm{NO}_{3_{S_{-} W t r}}=\left(1-\text { Comp }_{\text {Moist.Cont }}\right) \times N_{c} \times N_{\text {frac.NO}_{3}} \times\left(1-\text { frac }_{G W}\right) \\
& N_{f}=\left(1-\text { Comp }_{\text {Moist.Cont }}\right) \times N_{c} \times M F E N
\end{aligned}
$$




$$
\begin{aligned}
& P_{f}=\left(1-\text { Comp }_{\text {Moist.Cont }}\right) \times P_{c} \times M F E P \\
& K_{f}=\left(1-\text { Comp }_{\text {Moist.Cont }}\right) \times K_{c} \times M F E K \\
& D s l_{c}=\operatorname{Comp}_{\text {mass }} \times D s l_{c} \\
& D s l_{f e r t}=N_{f} \times D s l_{N . f}+P_{f e r} \times D s l_{P . f}+K_{f e r t} \times D s l_{K . f} \\
& N_{2} O_{\text {Emit.f }}=N_{f} \times N_{\text {frac. } \mathrm{N}_{2} \mathrm{O}} \times R_{N_{2} O . f}
\end{aligned}
$$

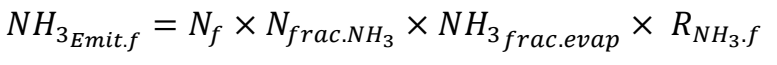

$$
\begin{aligned}
& \mathrm{NO}_{3_{G_{W t r . f}}}=N_{f} \times N_{\text {frac. } \mathrm{NO}_{3}} \times \mathrm{frac}_{G W} \times R_{\mathrm{NO}_{3} . f} \\
& \mathrm{NO}_{3_{S_{W t r . f}}}=N_{f} \times N_{\text {frac } . \mathrm{NO}_{3}} \times\left(1-\mathrm{frac}_{G W}\right) \times R_{\mathrm{NO}_{3} . f}
\end{aligned}
$$

Eq S14

Eq S15

Eq S16

Eq $\mathbf{S 1 7}$

Eq S18

Eq S19

Eq S20

Eq S21

Nutrient balance in ADC scenario:

$$
\begin{aligned}
& \mathrm{NH}_{4 \text { G.Wtr.ADC }}=\left(1-\text { Comp }_{\text {Moist.Cont }}\right) \times N_{c} \times N_{\text {frac.NH4 }} \times\left(1-L_{C R S_{\text {eff }}}\right) \\
& \mathrm{NH}_{4 \text { S.Wtr.ADC }}=\left(1-\text { Comp }_{\text {Moist.Cont }}\right) \times N_{c} \times N_{\text {frac.NH } 4} \times L C R S_{\text {eff }} \times\left(1-N H_{4} \text { rmv.eff }\right) \\
& \mathrm{NO}_{3 \text { S.Wtr.ADC }}=\left(1-\text { Comp }_{\text {Moist.Cont }}\right) \times N_{c} \times N_{\text {frac.NH } 4} \times L_{C R S_{\text {eff }}} \times N_{4_{\text {rmv.eff }}}
\end{aligned}
$$

Eq S23

\section{Avoided peat consumption:}

$$
\begin{aligned}
& \text { Peat }=\frac{\text { Comp }_{\text {mass }}}{\operatorname{Comp}_{\text {Dens }}} \times \text { Peat }_{\text {Subs.fac }} \times \text { Peat }_{\text {Dens }} \\
& \mathrm{CO}_{2_{\text {emit }-p}}=\text { Peat } \times\left(1-\text { Peat }_{\text {Moist.Cont }}\right) \times \text { Peat }_{\text {C.Cont }} \times\left(1-C_{\text {stor.p }}\right)
\end{aligned}
$$

Avoided soil excavation:

$$
\text { Excav }_{\text {Avoided }}=\frac{\text { Comp }_{\text {mass }}}{\operatorname{Comp}_{\text {Dens }}} \times \frac{1}{A D C_{\text {thick }}} \times D C_{\text {thick }} \times D C_{\text {subs.fac }}
$$




\section{Compost properties}

Table S1. Reported properties of OFMSW-derived compost.

\begin{tabular}{lllll}
\hline & $\begin{array}{l}\text { Garden waste } \\
\text { compost }^{1}\end{array}$ & $\begin{array}{l}\text { Food waste } \\
\text { compost }^{2}\end{array}$ & $\begin{array}{l}\text { Garden waste } \\
\text { compost }^{2}\end{array}$ & $\begin{array}{l}\text { Kitchen waste } \\
\text { compost }^{3}\end{array}$ \\
\hline Moisture $(\% \mathrm{TW})$ & $20.8-50.4$ & $18-67$ & $29-44$ & $40-77$ \\
Density $\left(\mathrm{kg} / \mathrm{m}^{3}\right)$ & $450-900$ & - & - & $400-500$ \\
$\mathrm{C}(\% \mathrm{TS})$ & $9.7-18.9$ & $19.1-47$ & $10-28.5$ & $19-47$ \\
$\mathrm{~N}(\% \mathrm{TS})$ & $0.72-1$ & $0.9-2.8$ & $0.7-1.55$ & $1.7-2.8$ \\
$\mathrm{P}(\% \mathrm{TS})$ & $0.12-0.21$ & $0.18-0.93$ & $0.15-0.73$ & $0.25-0.7$ \\
K $(\% \mathrm{TS})$ & $1.42-1.98$ & $0.34-2.3$ & $0.77-1.94$ & $0.87-2.3$ \\
\hline
\end{tabular}

\section{GWP characterization factors}

Table S2. Selected GWP values based IPCC $2013^{4}$ and $2007^{5}$, and two carbon accounting methods described in Table S3.

\begin{tabular}{|c|c|c|c|c|}
\hline & $\begin{array}{c}\text { IPCC } 2013, \\
\text { Ecoinvent V3.5, } \\
\text { GWP 100a, } \\
\text { bioCO }_{2}=0\end{array}$ & $\begin{array}{c}\text { IPCC } 2013, \\
\text { Ecoinvent V3.5, } \\
\text { GWP } 100 \mathrm{a}, \\
\text { bioCO }_{2}=1\end{array}$ & $\begin{array}{c}\text { IPCC } 2007, \\
\text { Ecoinvent V3.5, } \\
\text { GWP } 100 \mathrm{a}, \\
\text { bioCO }_{2}=0\end{array}$ & $\begin{array}{c}\text { IPCC 2007, } \\
\text { Ecoinvent V3.5, } \\
\text { GWP 100a, } \\
\text { bioCO }_{2}=1\end{array}$ \\
\hline Carbon dioxide, non-fossil & 0 & 1 & 0 & 1 \\
\hline Carbon dioxide, fossil & 1 & 1 & 1 & 1 \\
\hline $\begin{array}{l}\text { Carbon dioxide, from } \\
\text { soil or biomass stock }\end{array}$ & 1 & 0 & 1 & 0 \\
\hline Carbon monoxide, non-fossil & 0 & 4.0624 & 0 & 1.5714 \\
\hline Carbon monoxide, fossil & 4.0624 & 4.0624 & 1.5714 & 1.5714 \\
\hline $\begin{array}{l}\text { Carbon monoxide, from } \\
\text { soil or biomass stock }\end{array}$ & 4.0624 & 0 & 1.5714 & 0 \\
\hline Dinitrogen monoxide & 264.8 & 264.8 & 298 & 298 \\
\hline Methane, fossil & 36 & 36 & 25 & 25 \\
\hline $\begin{array}{l}\text { Methane, from soil } \\
\text { or biomass stock }\end{array}$ & 36 & 36 & 25 & 25 \\
\hline Methane, non-fossil & 36 & 36 & 22.25 & 25 \\
\hline
\end{tabular}

Table S3. Carbon accounting methods used for calculating the GWP.

\begin{tabular}{|c|c|c|c|c|}
\hline GWP Methods & $\mathrm{CO}_{2}-$ Fossil & $\mathrm{CO}_{2}$ - Biogenic & $\begin{array}{l}\text { Fossil C Stored } \\
\quad\left(\text { as } \mathrm{CO}_{2}\right)\end{array}$ & $\begin{array}{l}\text { Biogenic C Stored } \\
\quad\left(\text { as } \mathrm{CO}_{2}\right)\end{array}$ \\
\hline $\begin{array}{l}\text { Biogenic } \mathrm{CO}_{2} \text { emissions } \\
\text { are equivalent to fossil } \mathrm{CO}_{2}\end{array}$ & 1 & 1 & 0 & 0 \\
\hline $\begin{array}{l}\text { Neutral Biogenic } \mathrm{CO}_{2} \\
\text { emissions }\end{array}$ & 1 & 0 & 0 & -1 \\
\hline
\end{tabular}




\section{Carbon fate in ADC scenario:}

Table S4 presents the calculation of compost's carbon fate in a landfill. The carbon loss during composting and AD are calculated based on Levis and Barlaz (2013). ${ }^{6,7}$ These carbon losses are compared to the ultimate carbon loss under anaerobic conditions in a landfill after 100 years; ${ }^{8}$ if the carbon loss in composting or AD was more than carbon loss in a landfill, then it was assumed that all the carbon content of the compost remains stored when it is used as ADC, while if the carbon loss in composting or $\mathrm{AD}$ was smaller, then it was assumed that the carbon content of the compost decomposes to landfill gas, until the carbon loss reaches the reported value for carbon loss in a landfill.

Table S4. Potential carbon storage and losses during aerobic and anaerobic decomposition.

\begin{tabular}{|c|c|c|c|c|c|c|}
\hline Row & Properties & $\begin{array}{c}\text { Yard } \\
\text { Trimmings, } \\
\text { Leaves }\end{array}$ & $\begin{array}{c}\text { Yard } \\
\text { Trimmings, } \\
\text { Grass }\end{array}$ & $\begin{array}{c}\text { Yard } \\
\text { Trimmings, } \\
\text { Branches }\end{array}$ & $\begin{array}{c}\text { Food } \\
\text { Waste - } \\
\text { Vegetable }\end{array}$ & $\begin{array}{c}\text { Food Waste } \\
\text { - Non- } \\
\text { Vegetable }\end{array}$ \\
\hline 1 & Moisture Content (\%Wet) & $8.7^{9}$ & $70.1^{10}$ & $8.4^{9}$ & $78.3^{10}$ & $70.6^{11}$ \\
\hline 2 & Biogenic C Content (\% TS) & $43.7^{9}$ & $44.8^{10}$ & $44.2^{9}$ & $49.1^{10}$ & $48.4^{11}$ \\
\hline 3 & $\begin{array}{l}\text { Ultimate Biogenic C Converted to Biogas } \\
\text { Anaerobically in Landfill (\%TC) }\end{array}$ & $15.4^{8}$ & $46.5^{8}$ & $23.1^{8}$ & $82.9^{8}$ & $70.0^{8}$ \\
\hline 4 & Potential C storage in Landfill (\%TC) & $84.6^{8}$ & $53.5^{8}$ & $76.9^{8}$ & $17.1^{8}$ & $30.0^{8}$ \\
\hline 5 & $\begin{array}{l}\text { Percent C-loss during Aerobic Composting } \\
\text { (\%TC) }\end{array}$ & $57.2^{7}$ & $57.2^{7}$ & $57.2^{7}$ & $65.7^{7}$ & $65.7^{7}$ \\
\hline 6 & C storage for compost as ADC & 100.0 & 100.0 & 100.0 & 49.9 & 87.5 \\
\hline 7 & $\begin{array}{l}\text { Percent C-loss in Anaerobic Digestion } \\
\text { reactor }(\% \mathrm{TC})\end{array}$ & $12.8^{6}$ & $38.8^{6}$ & $9.6^{6}$ & $69.1^{6}$ & $58.3^{6}$ \\
\hline 8 & $\begin{array}{l}\text { Percent C-loss during Anaerobic Digestion } \\
\text { followed by aerobic Curing (\%TC) }\end{array}$ & 57.2 & 57.2 & 57.2 & 69.1 & 58.3 \\
\hline 9 & C storage for cured digestate as ADC & 100.0 & 100.0 & 100.0 & 55.3 & 72.0 \\
\hline
\end{tabular}

After calculating the percent of compost $\mathrm{C}$ that decomposes to landfill gas in a landfill, collection efficiency, percent of collected gas that is flared and percent of uncollected that is oxidized are used to define the fate of landfill gas (Table S5). Four decay rates and 10,000 different combinations of food and yard wastes as a feedstock for composting or AD are used to calculate the distributions for carbon storage and landfill gas collection, oxidation, and flared parameters. The 10,000 feedstock compositions are generated randomly and assume that the feedstock contains $31 \%$ food waste (random combination of vegetable and non-vegetable) and $69 \%$ yard waste (random combination of grass, branches and leaves) based on waste generation rates ${ }^{12}$ and waste collection efficiencies in the US. ${ }^{13}$ The process for producing compost (composting or AD) and decay rate $\left(0.02,0.04,0.06\right.$, or $\left.0.012 \mathrm{yr}^{-1}\right)$ are also selected randomly. The calculated distributions are presented in Table S6. 
Table S5. Landfill gas fate in a landfill with decay rates of 0.02, 0.04, 0.06, and 0.12. (Calculated with the landfill model in SWOLF ${ }^{14}$ ).

\begin{tabular}{|c|c|c|c|c|c|}
\hline & $\begin{array}{c}\text { Yard Trimmings, } \\
\text { Leaves }\end{array}$ & $\begin{array}{c}\text { Yard Trimmings, } \\
\text { Grass }\end{array}$ & $\begin{array}{c}\text { Yard Trimmings, } \\
\text { Branches }\end{array}$ & $\begin{array}{l}\text { Food Waste } \\
\text { Vegetable }\end{array}$ & $\begin{array}{c}\text { Food Waste } \\
\text { Non-Vegetable }\end{array}$ \\
\hline \multicolumn{6}{|c|}{ Decay rate $0.02 \mathrm{yr}^{-1}$} \\
\hline Collection $^{\text {a }}$ & $70 \%$ & $71 \%$ & $40 \%$ & $68 \%$ & $68 \%$ \\
\hline Oxidation $^{\mathrm{b}}$ & $19 \%$ & $13 \%$ & $31 \%$ & $21 \%$ & $21 \%$ \\
\hline Flare $^{\mathrm{c}}$ & $15 \%$ & $22 \%$ & $5 \%$ & $20 \%$ & $22 \%$ \\
\hline \multicolumn{6}{|c|}{ Decay rate $0.04 \mathrm{yr}^{-1}$} \\
\hline Collection $^{\mathrm{a}}$ & $70 \%$ & $63 \%$ & $45 \%$ & $71 \%$ & $71 \%$ \\
\hline Oxidation $^{\mathrm{b}}$ & $13 \%$ & $11 \%$ & $30 \%$ & $14 \%$ & $14 \%$ \\
\hline Flare $^{\mathrm{c}}$ & $24 \%$ & $36 \%$ & $8 \%$ & $31 \%$ & $34 \%$ \\
\hline \multicolumn{6}{|c|}{ Decay rate 0.06 yr $^{-1}$} \\
\hline Collection $^{\text {a }}$ & $65 \%$ & $56 \%$ & $49 \%$ & $67 \%$ & $67 \%$ \\
\hline Oxidation ${ }^{b}$ & $11 \%$ & $11 \%$ & $30 \%$ & $12 \%$ & $12 \%$ \\
\hline Flare $^{\mathrm{c}}$ & $32 \%$ & $44 \%$ & $11 \%$ & $41 \%$ & $46 \%$ \\
\hline \multicolumn{6}{|c|}{ Decay rate $0.12 \mathrm{yr}^{-1}$} \\
\hline Collection $^{\mathrm{a}}$ & $54 \%$ & $45 \%$ & $60 \%$ & $57 \%$ & $57 \%$ \\
\hline Oxidation ${ }^{b}$ & $11 \%$ & $10 \%$ & $26 \%$ & $11 \%$ & $11 \%$ \\
\hline Flare $^{c}$ & $47 \%$ & $55 \%$ & $16 \%$ & $62 \%$ & $70 \%$ \\
\hline
\end{tabular}

a Percent of produced $\mathrm{CH}_{4}$ that if collected.

${ }^{b}$ Percent of uncollected $\mathrm{CH}_{4}$ that is oxidized.

${ }^{\mathrm{c}}$ Percent of collected $\mathrm{CH}_{4}$ that is flared.

Table S6. Parameters related to carbon fate in ADC scenario.

\begin{tabular}{lllll}
\hline & $\mathrm{CH}_{4 \mathrm{Col}}$ & $\mathrm{CH}_{4 \mathrm{Ox}}$ & $\mathrm{CH}_{4_{\mathrm{Flr}}}$ & $\mathrm{C}_{\text {Stor }}$ \\
\hline Average & $60 \%$ & $17 \%$ & $31 \%$ & $90 \%$ \\
Standard deviation & $4 \%$ & $3.5 \%$ & $12.1 \%$ & $3 \%$ \\
Max & $69.7 \%$ & $27.9 \%$ & $59.3 \%$ & $97.5 \%$ \\
Min & $48.7 \%$ & $10.5 \%$ & $10.0 \%$ & $83.2 \%$ \\
\hline
\end{tabular}




\section{Supplemental results}

Table S7. The frequency (\%) with which each scenario outperformed the other in each impact category for the base scenarios. The performance of two scenarios is considered tied when the difference between their score is less than $10 \%$ of the higher score.

\begin{tabular}{|c|c|c|c|c|c|c|}
\hline & & $\begin{array}{c}\mathrm{GWP} \\
\left(\mathrm{kg} \mathrm{CO}_{2} \mathrm{e}\right)\end{array}$ & $\begin{array}{c}\text { Acidification } \\
\left(\mathrm{kg} \mathrm{SO}_{2} \mathrm{e}\right)\end{array}$ & $\begin{array}{c}\text { Eutrophication } \\
(\mathrm{kg} \mathrm{N} \mathrm{e})\end{array}$ & $\begin{array}{l}\text { CED } \\
\text { (MJe) }\end{array}$ & $\begin{array}{c}\text { ADP } \\
\text { (kg antimony e) }\end{array}$ \\
\hline \multirow{3}{*}{$\begin{array}{c}\text { Fertilizer } \\
\text { offset }\end{array}$} & $\mathrm{ADC}$ & 100 & 80 & 100 & 4 & 0 \\
\hline & Tie performance & 0 & 1 & 0 & 2 & 0 \\
\hline & Soil amendment & 0 & 19 & 0 & 94 & 100 \\
\hline \multirow{3}{*}{ Peat offset } & $\mathrm{ADC}$ & 82 & 99 & 100 & 0 & 2 \\
\hline & Tie performance & 4 & 0 & 0 & 0 & 2 \\
\hline & Soil amendment & 14 & 1 & 0 & 100 & 96 \\
\hline \multirow{3}{*}{$\begin{array}{c}\text { Both } \\
\text { Fertilizer and } \\
\text { Peat offsets }\end{array}$} & $\mathrm{ADC}$ & 63 & 77 & 100 & 0 & 0 \\
\hline & Tie performance & 6 & 1 & 0 & 0 & 0 \\
\hline & Soil amendment & 31 & 22 & 0 & 100 & 100 \\
\hline
\end{tabular}

Table S8. The frequency (\%) with which each scenario outperformed the other when using four different sets of GWPs. The performance of two scenarios is considered tied when the difference between their score is less than $10 \%$ of the higher score.

\begin{tabular}{|c|c|c|c|c|c|}
\hline \multirow{5}{*}{$\begin{array}{l}\text { Method for } \\
\text { calculating } \\
\text { GWP }\end{array}$} & Method & IPCC 2013 & IPCC 2013 & IPCC 2007 & IPCC 2007 \\
\hline & $\mathrm{GWP}$ for non-fossil $\mathrm{CO}_{2}$ & 1 & 0 & 1 & 0 \\
\hline & GWP for non-fossil $\mathrm{CH}_{4}$ & 36 & 36 & 25 & 22.5 \\
\hline & GWP for $\mathrm{N}_{2} \mathrm{O}$ & 264.8 & 264.8 & 298 & 298 \\
\hline & Unit & $\left(\mathrm{kg} \mathrm{CO}_{2} \mathrm{e}\right)$ & $\left(\mathrm{kg} \mathrm{CO}_{2} \mathrm{e}\right)$ & $\left(\mathrm{kg} \mathrm{CO}_{2} \mathrm{e}\right)$ & $\left(\mathrm{kg} \mathrm{CO}_{2} \mathrm{e}\right)$ \\
\hline \multirow{3}{*}{ Fertilizer offset } & $\mathrm{ADC}$ & 100 & 100 & 100 & 100 \\
\hline & Tie performance & 0 & 0 & 0 & 0 \\
\hline & Soil amendment & 0 & 0 & 0 & 0 \\
\hline \multirow{3}{*}{ Peat offset } & $\mathrm{ADC}$ & 82 & 79 & 87 & 85 \\
\hline & Tie performance & 4 & 8 & 2 & 6 \\
\hline & Soil amendment & 14 & 13 & 11 & 9 \\
\hline \multirow{3}{*}{$\begin{array}{l}\text { Both Fertilizer } \\
\text { and Peat offsets }\end{array}$} & $\mathrm{ADC}$ & 63 & 60 & 71 & 70 \\
\hline & Tie performance & 6 & 13 & 4 & 11 \\
\hline & Soil amendment & 31 & 27 & 25 & 19 \\
\hline
\end{tabular}




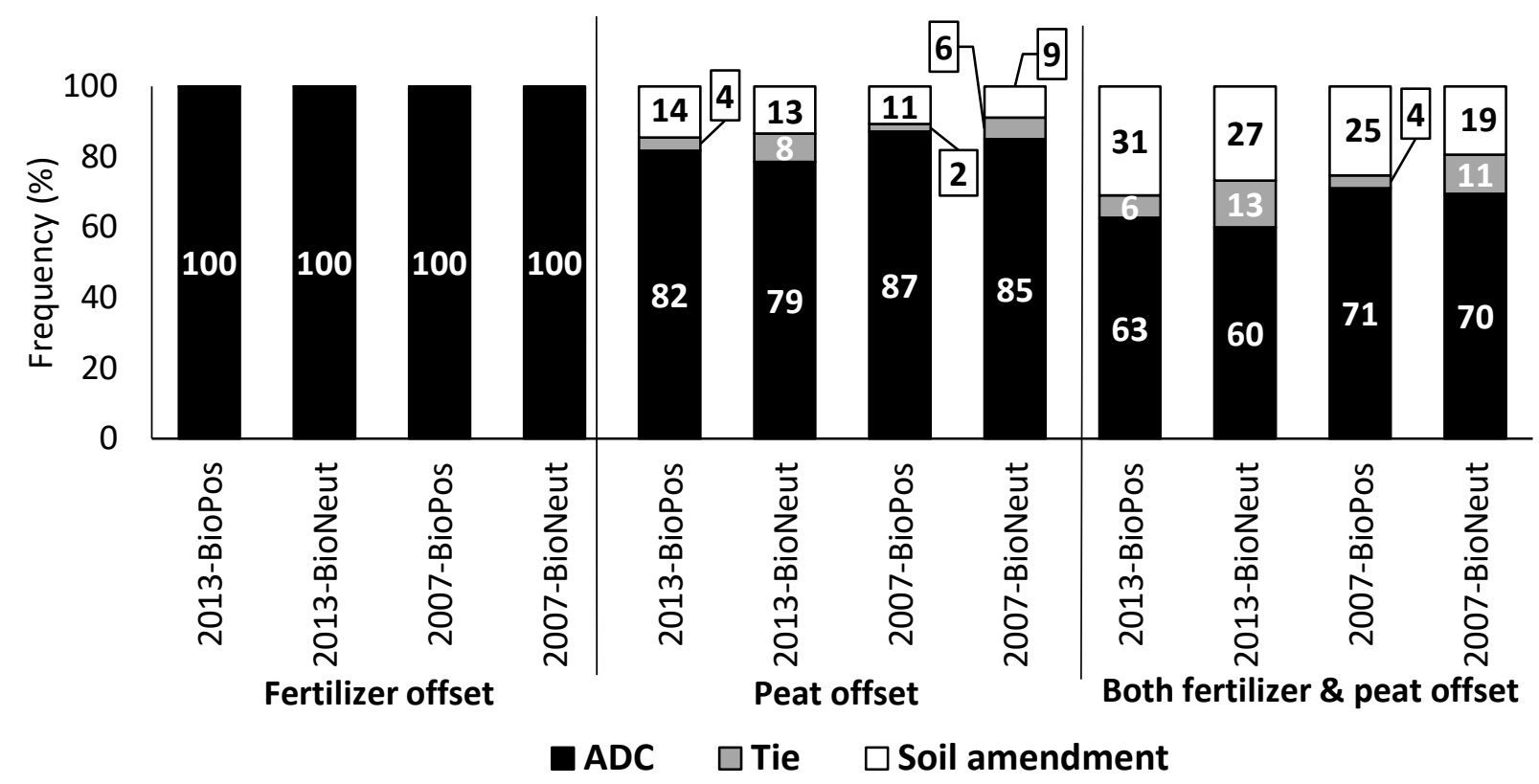

Figure S1. The fraction of Monte Carlo simulations in which each scenario outperformed the other in terms of GWP calculated according the IPCC 2007 or 2013 characterization factors. The performance of two scenarios is considered tied when the difference between their score is less than $10 \%$ of the higher score. 2013-BioPos and 2007-BioPos assume that biogenic $\mathrm{CO}_{2}$ emissions are equivalent to fossil $\mathrm{CO}_{2}$ while 2013-BioNeut and 2007-BioNeut assume that biogenic $\mathrm{CO}_{2}$ emissions are neutral.

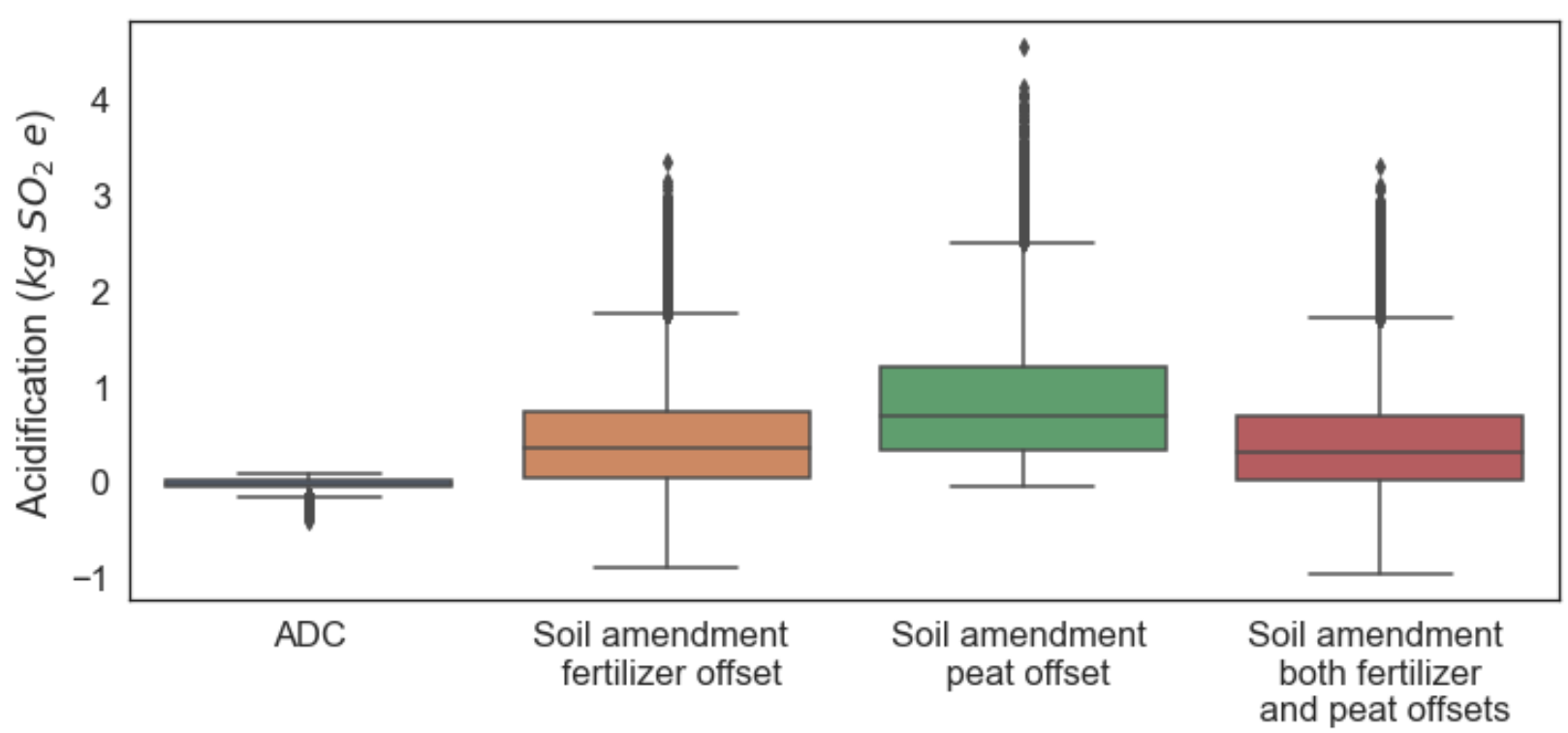

Figure S2. Distribution of acidification impacts for each of the scenarios assessed in the Monte Carlo analysis. The interior lines represent the median while the boxes bound the interquartile range (25th to 75 th quartile). The whiskers extend to 1.5 times the IQR, and their ends show the highest and lowest value excluding outliers, which are represented by diamonds. 


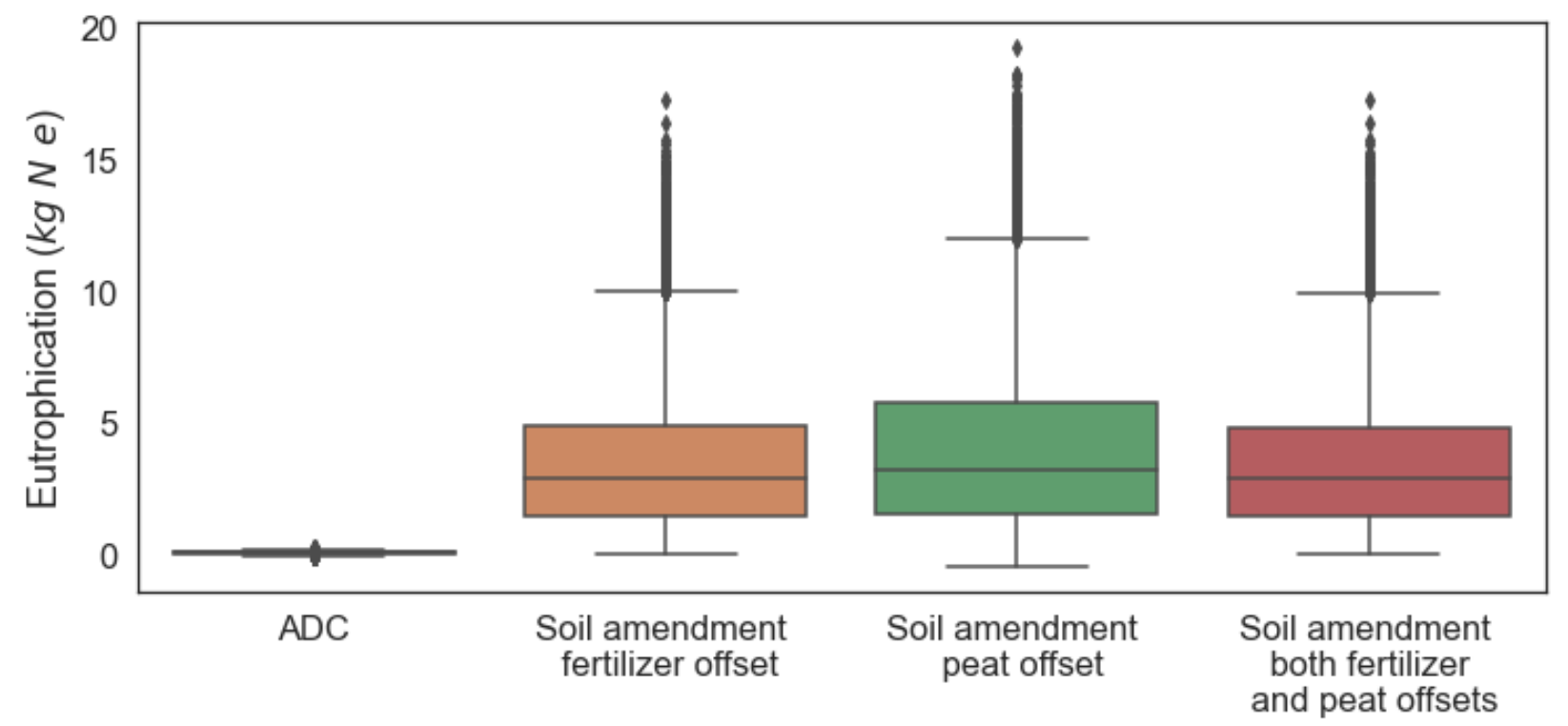

Figure S3. Distribution of eutrophication impacts for each of the scenarios assessed in the Monte Carlo analysis. The interior lines represent the median while the boxes bound the interquartile range (25th to 75 th quartile). The whiskers extend to 1.5 times the IQR, and their ends show the highest and lowest value excluding outliers, which are represented by diamonds.

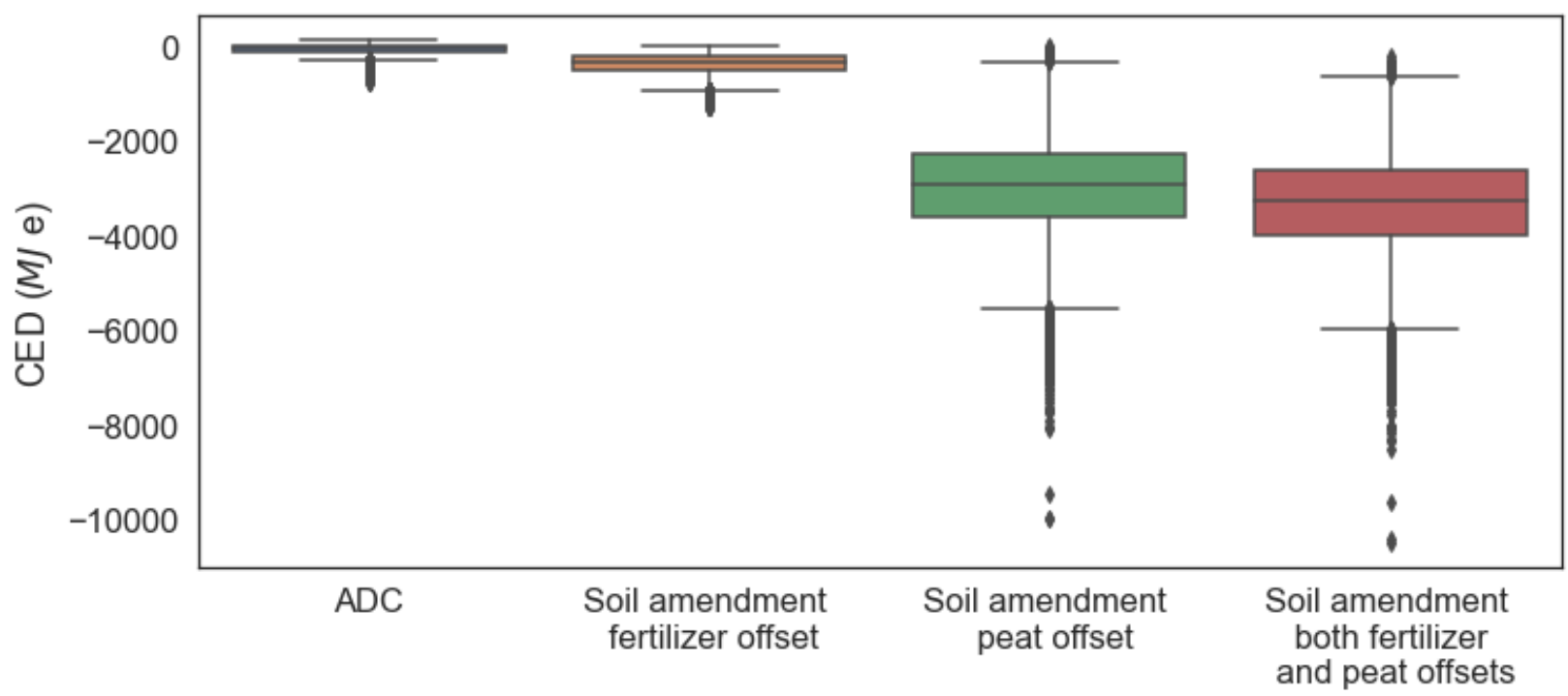

Figure S4. Distribution of cumulative fossil energy demand for each of the scenarios assessed in the Monte Carlo analysis. The interior lines represent the median while the boxes bound the interquartile range (25th to 75 th quartile). The whiskers extend to 1.5 times the IQR, and their ends show the highest and lowest value excluding outliers, which are represented by diamonds 


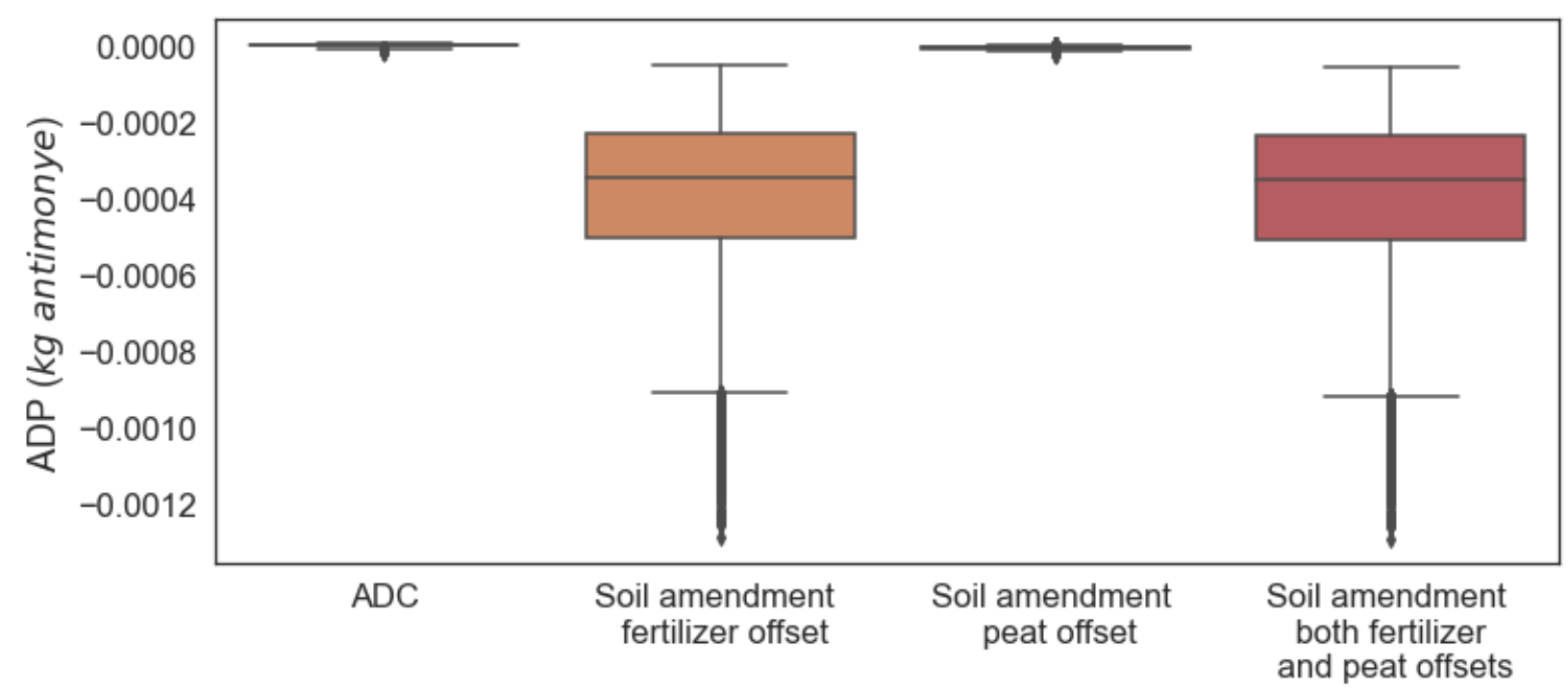

Figure S5. Distribution of abiotic depletion potential for each of the scenarios assessed in the Monte Carlo analysis. The interior lines represent the median while the boxes bound the interquartile range (25th to 75 th quartile). The whiskers extend to 1.5 times the IQR, and their ends show the highest and lowest value excluding outliers, which are represented by diamonds

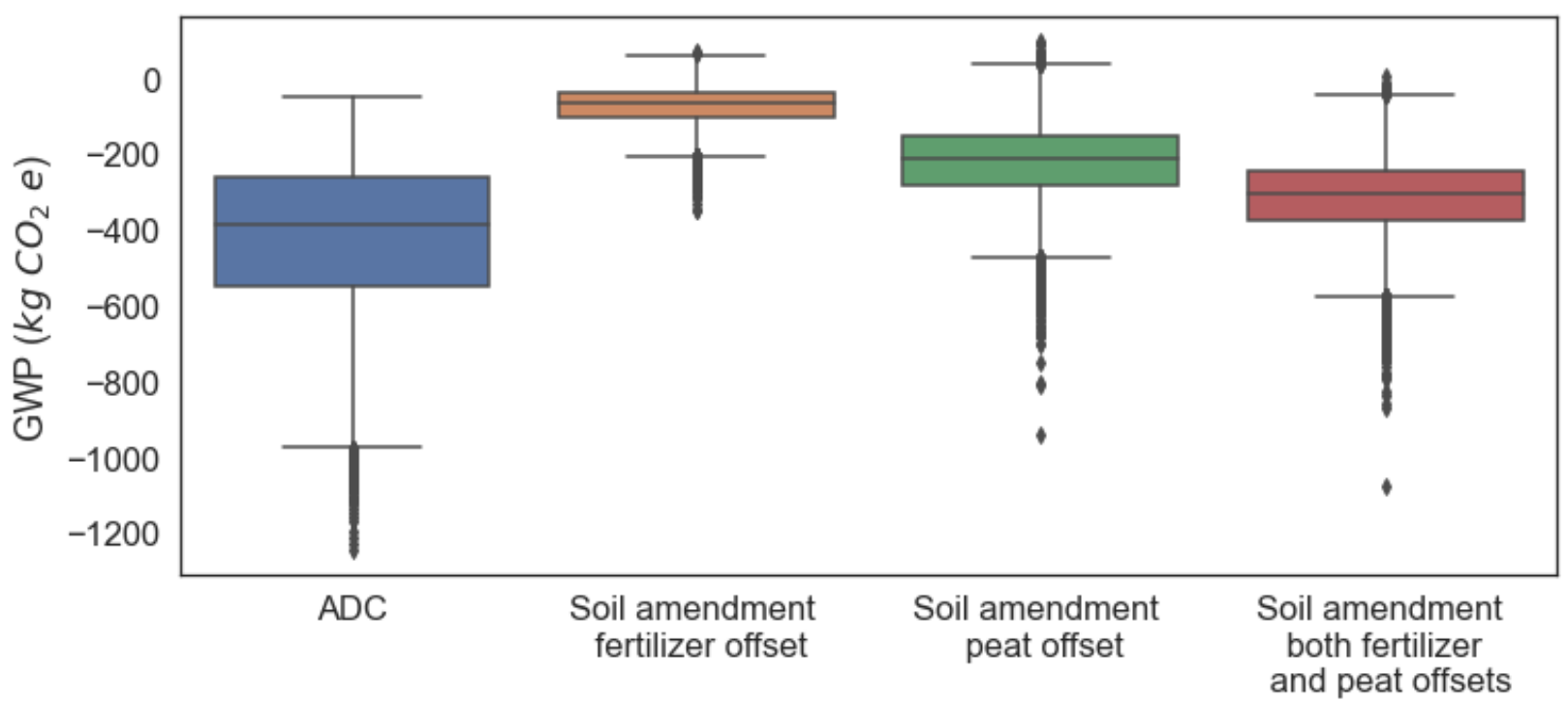

Figure S6. Distribution of global warming impacts (IPCC 2013, neutral biogenic $\mathrm{CO}_{2}$ ) for each of the scenarios assessed in the Monte Carlo analysis. The interior lines represent the median while the boxes bound the interquartile range (25th to 75 th quartile). The whiskers extend to 1.5 times the IQR, and their ends show the highest and lowest value excluding outliers, which are represented by diamonds. 


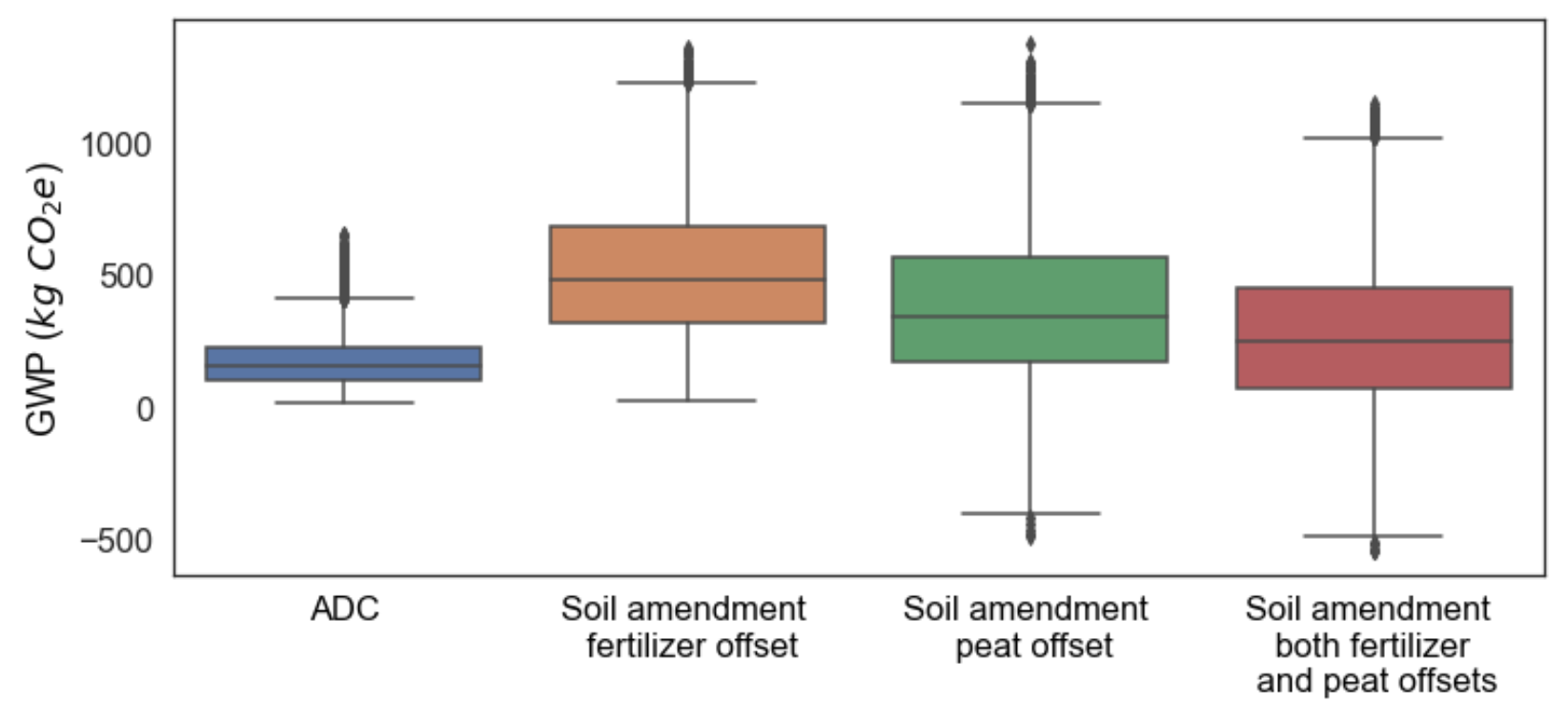

Figure S7. Distribution of global warming impacts (IPCC 2013, biogenic and fossil $\mathrm{CO}_{2}$ equal) for each of the scenarios assessed in the Monte Carlo analysis. The interior lines represent the median while the boxes bound the interquartile range (25th to 75 th quartile). The whiskers extend to 1.5 times the IQR, and their ends show the highest and lowest value excluding outliers, which are represented by diamonds.

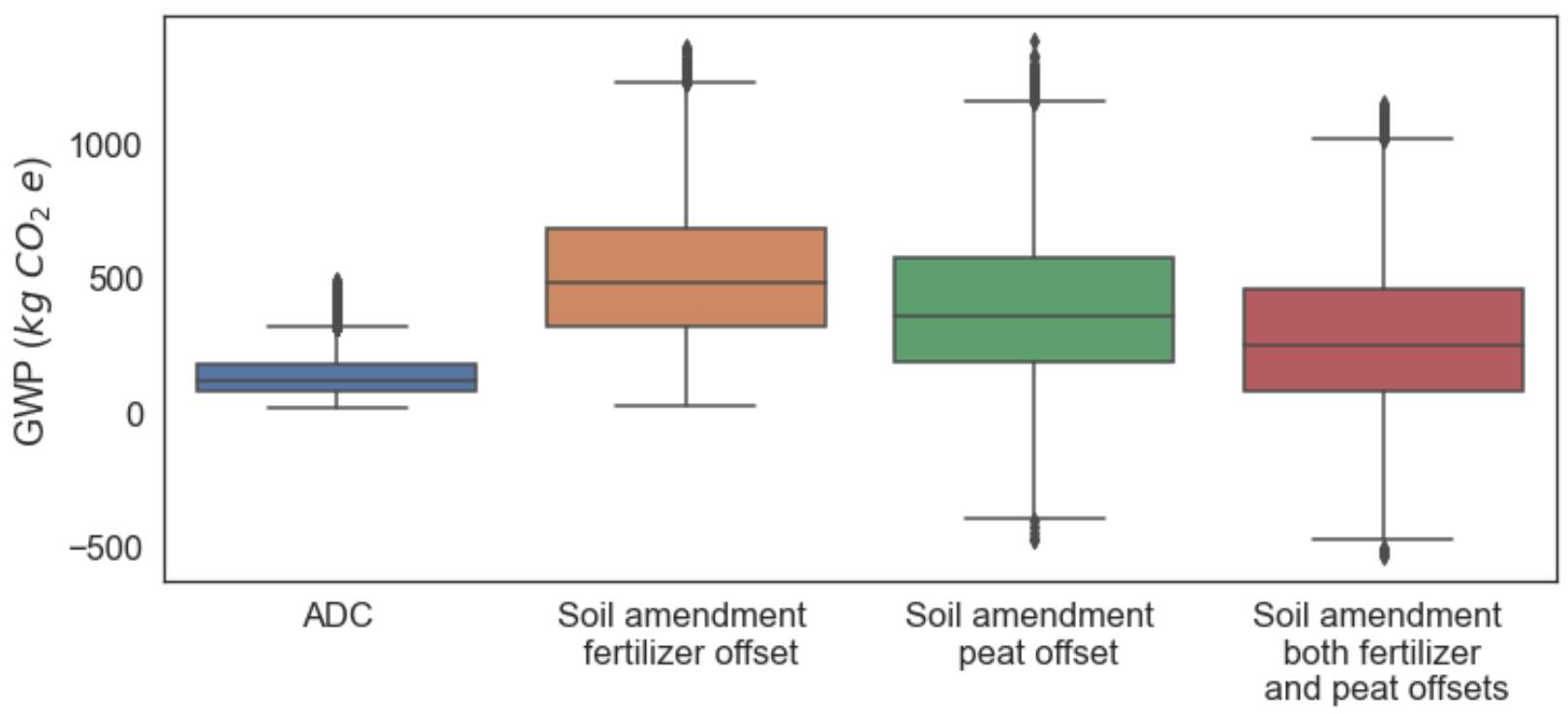

Figure S8. Distribution of global warming impacts (IPCC 2007, counting biogenic $\mathrm{CO}_{2}$ ) for each of the scenarios assessed in the Monte Carlo analysis. The interior lines represent the median while the boxes bound the interquartile range (25th to 75 th quartile). The whiskers extend to 1.5 times the IQR, and their ends show the highest and lowest value excluding outliers, which are represented by diamonds. 


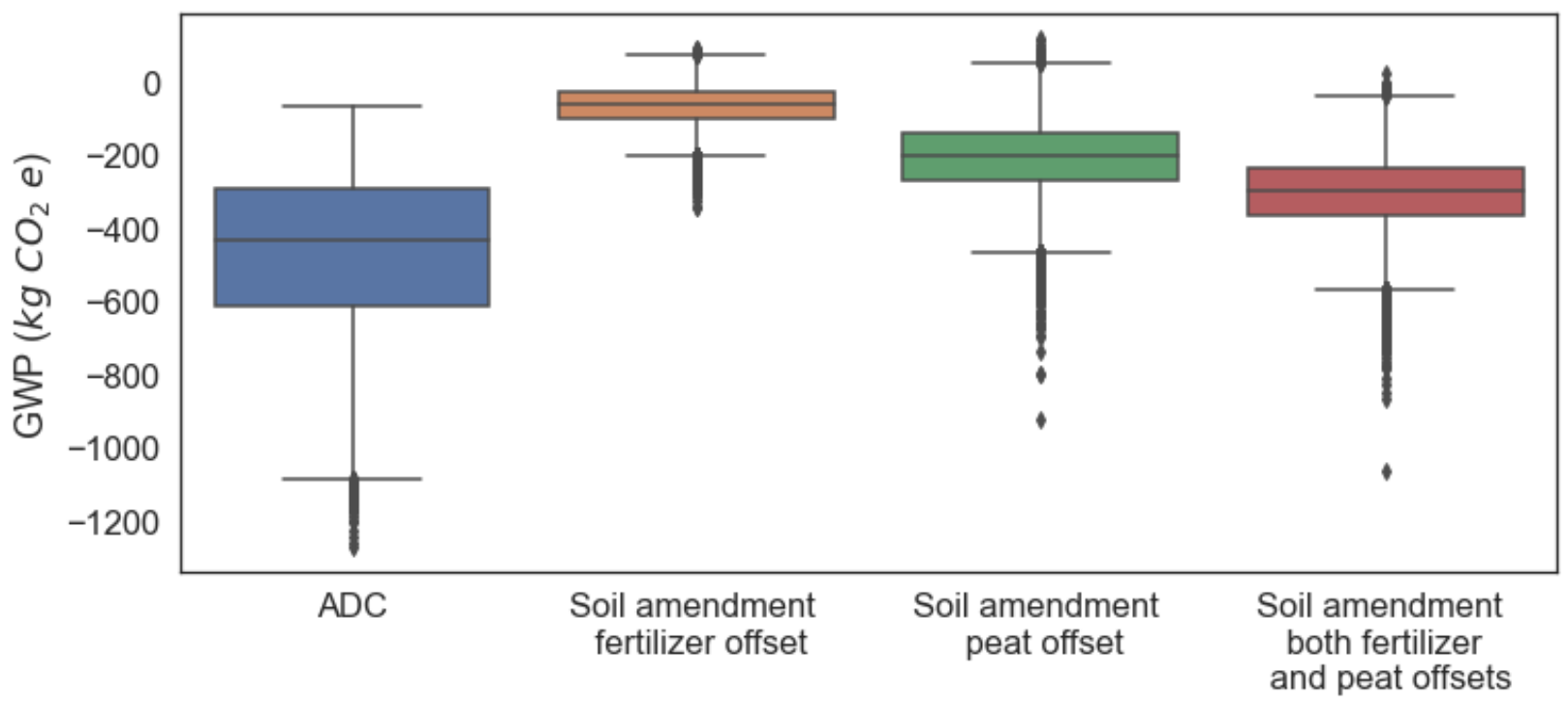

Figure S9. Distribution of global warming impacts (IPCC 2007, neutral biogenic $\mathrm{CO}_{2}$ ) for each of the scenarios assessed in the Monte Carlo analysis. The interior lines represent the median while the boxes bound the interquartile range (25th to 75 th quartile). The whiskers extend to 1.5 times the IQR, and their ends show the highest and lowest value excluding outliers, which are represented by diamonds. 


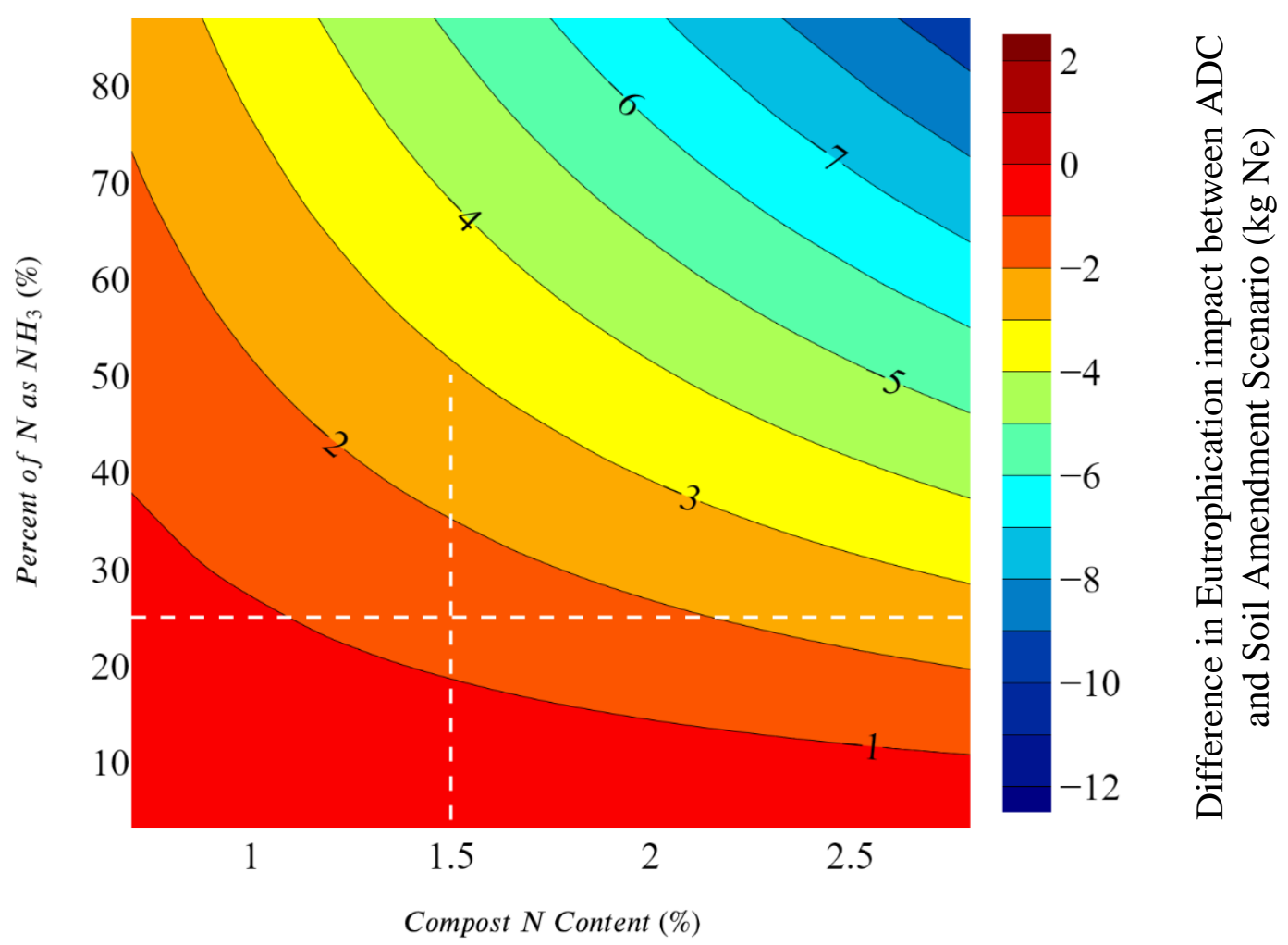

Figure S10. Dual parametric sensitivity analysis of the difference in eutrophication between the $\mathrm{ADC}$ and soil amendment (offsetting both peat and fertilizer) scenarios for selected inputs (kg Ne). Negative values indicate that the ADC scenario has lower eutrophication, while positive values indicate that the soil amendment scenario has lower eutrophication. The white dashed lines show the results when using the default input values. 


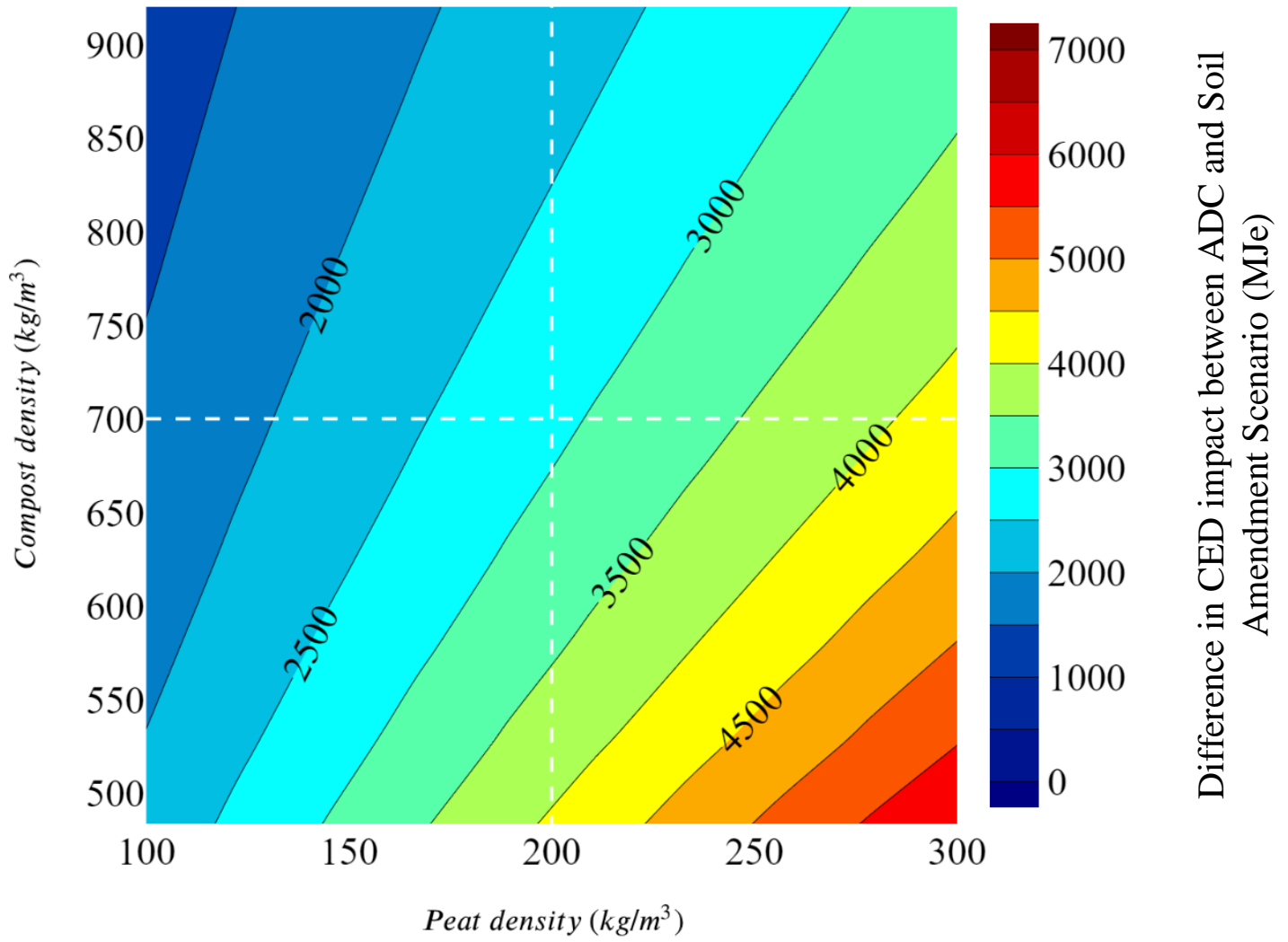

Figure S11. Dual parametric sensitivity analysis of the difference in CED between the ADC and soil amendment (offsetting both peat and fertilizer) scenarios for selected inputs (MJe). Positive values indicate that the soil amendment scenario has lower CED. The white dashed lines show the results when using the default input values. 


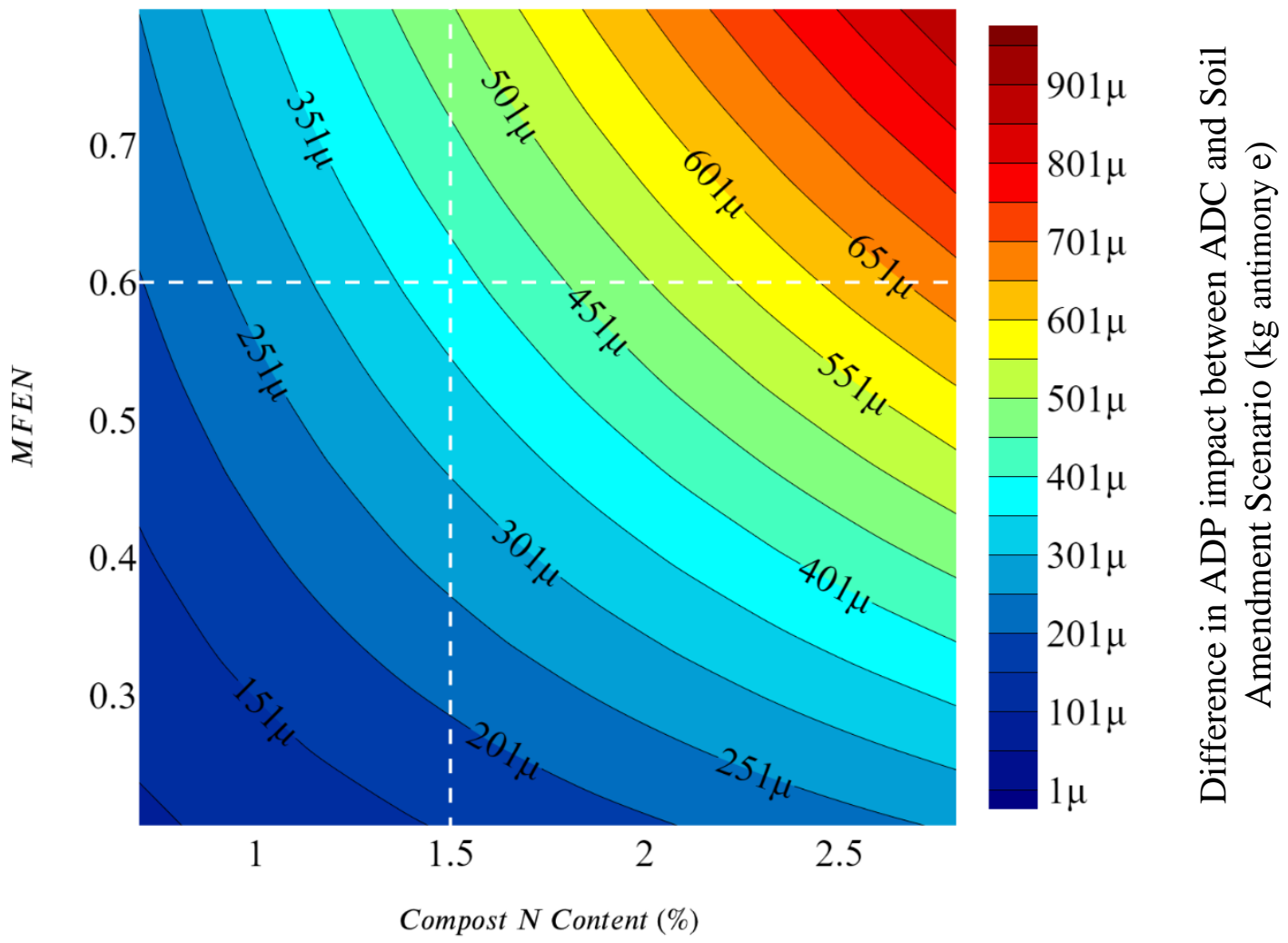

Figure S12. Dual parametric sensitivity analysis of the difference in ADP between the ADC and soil amendment (offsetting both peat and fertilizer) scenarios for selected inputs (kg antimony e). Positive values indicate that the soil amendment scenario has lower ADP. The white dashed lines show the results when using the default input values. 


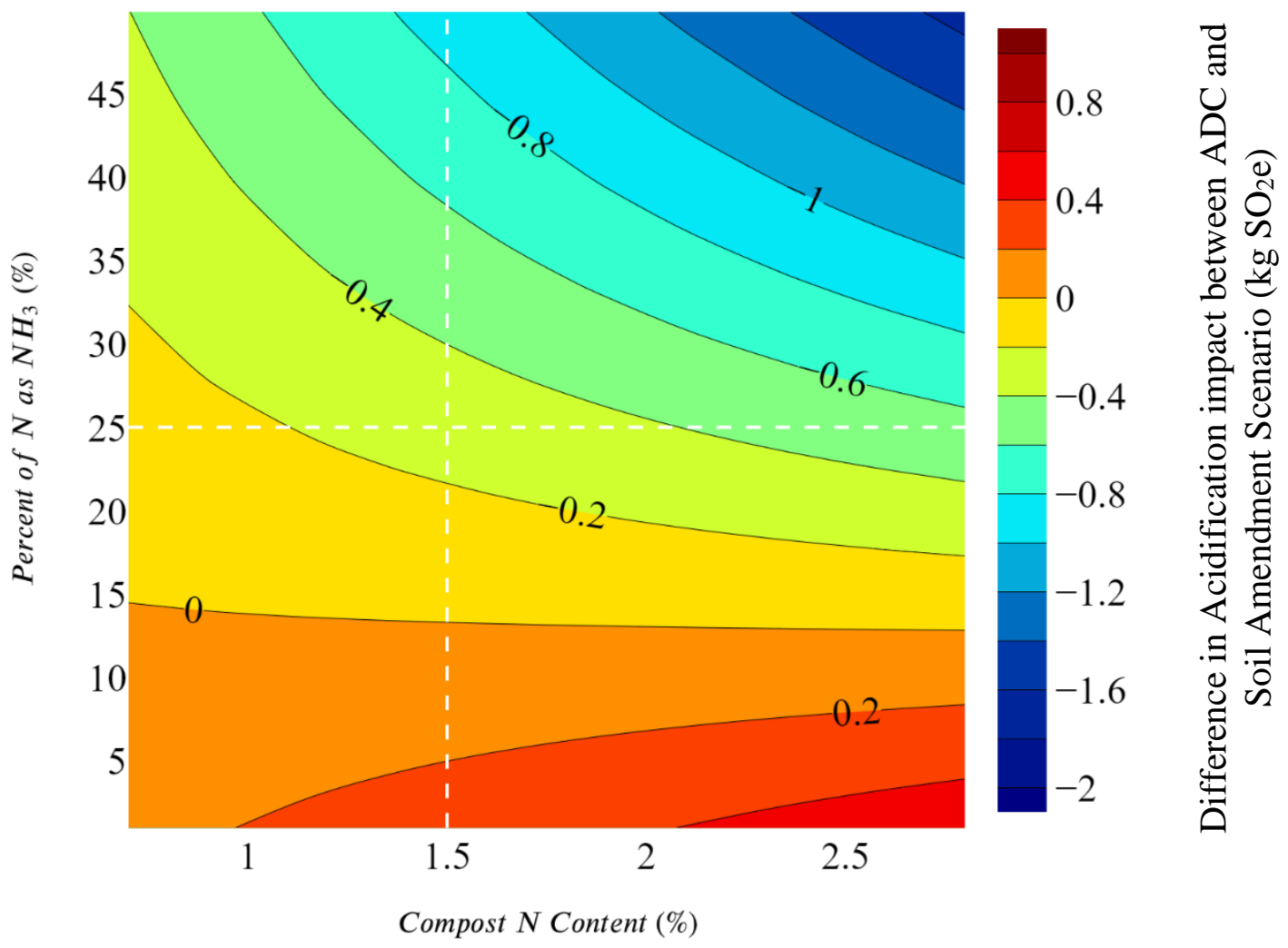

Figure S13. Dual parametric sensitivity analysis of the difference in acidification between the ADC and soil amendment (offsetting both peat and fertilizer) scenarios for selected inputs $\left(\mathrm{kg} \mathrm{SO}_{2} \mathrm{e}\right)$. Negative values indicate that the ADC scenario has lower acidification, while positive values indicate that the soil amendment scenario has lower acidification. The white dashed lines show the results when using the default input values. 


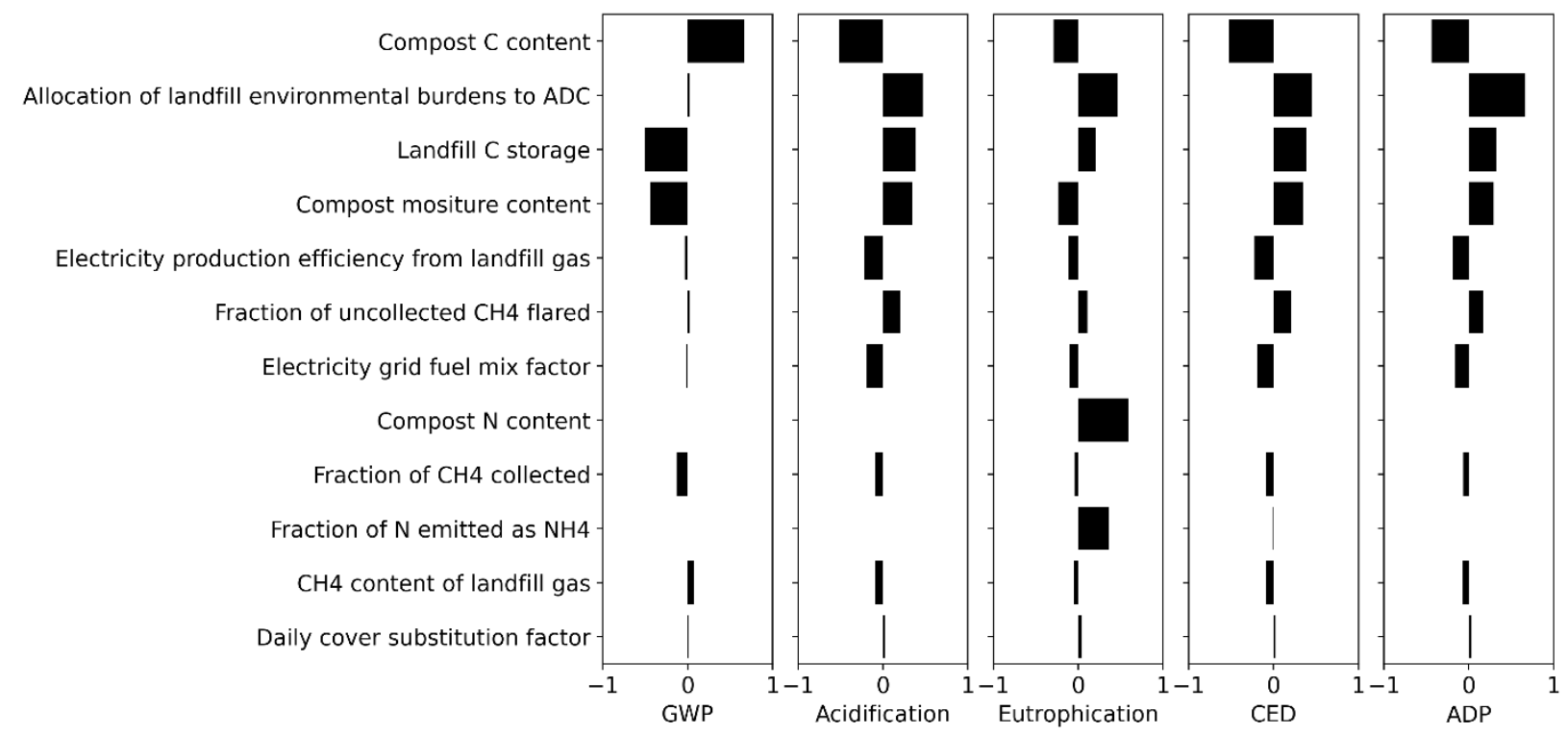

Figure S14. Spearman correlation of the ADC scenario's impacts with selected input parameters. A negative correlation indicates that increasing the parameter value decreases the impact, while positive correlations mean that increasing the parameter value increases the impact.
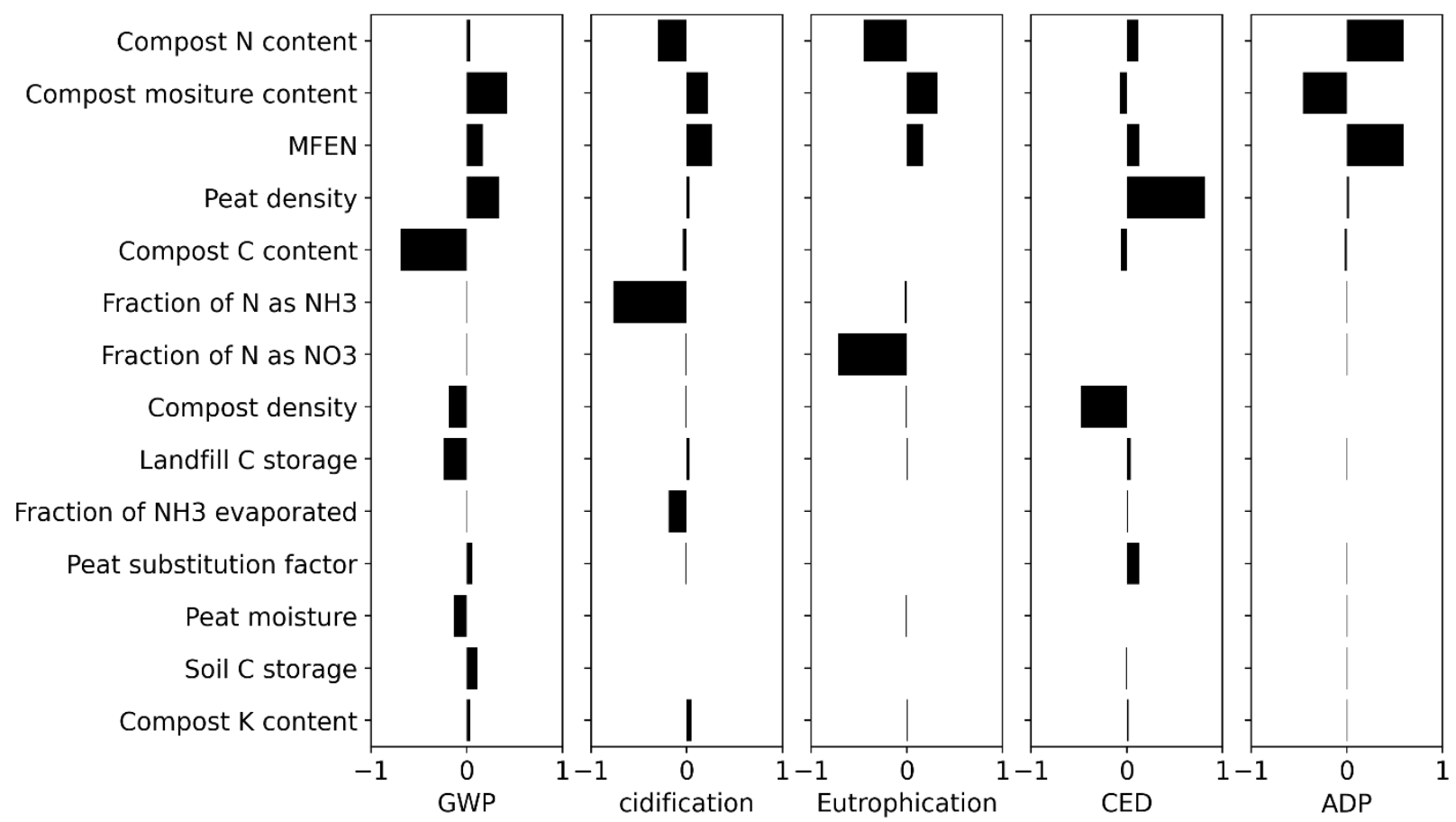

Figure S15. Spearman correlation of the soil amendment scenario's impacts with selected input parameters. A negative correlation indicates that increasing the parameter value decreases the impact, while positive correlations mean that increasing the parameter value increases the impact. 

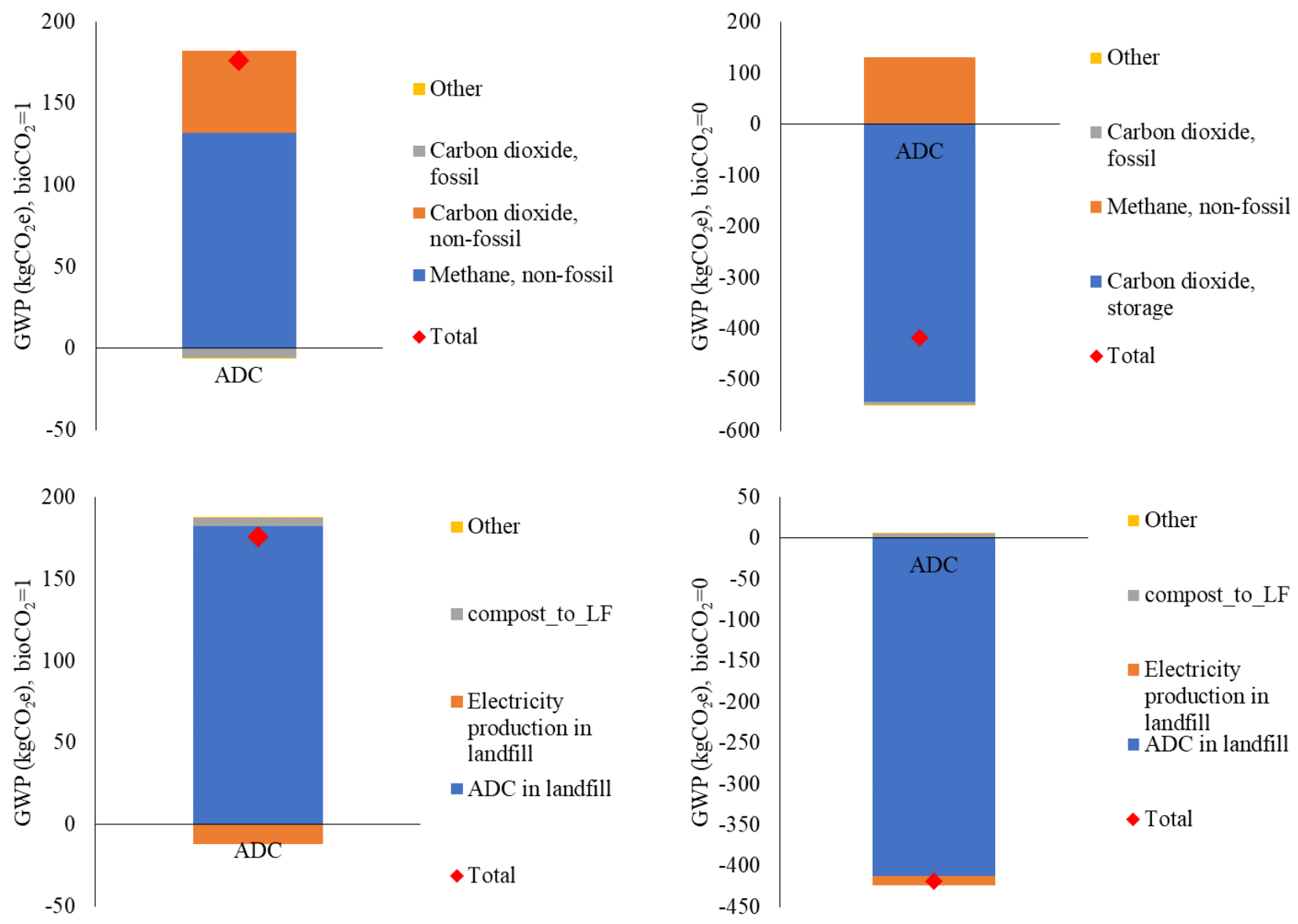

Figure S16. Breakdown of top emissions (top figures) and activities (bottom figures) that contribute to GWP of the ADC scenario according to the IPCC 2013 and assumptions that biogenic $\mathrm{CO}_{2}$ emissions are neutral (left figures) or equal to fossil $\mathrm{CO}_{2}$ emissions (right figures). 


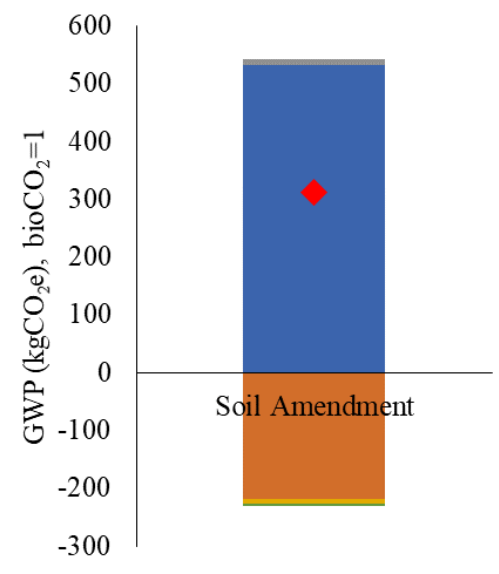

n Other

— Methane, non-fossi

- Dinitrogen

monoxide

- Carbon dioxide, fossil

- Carbon dioxide, non-fossil

- Total

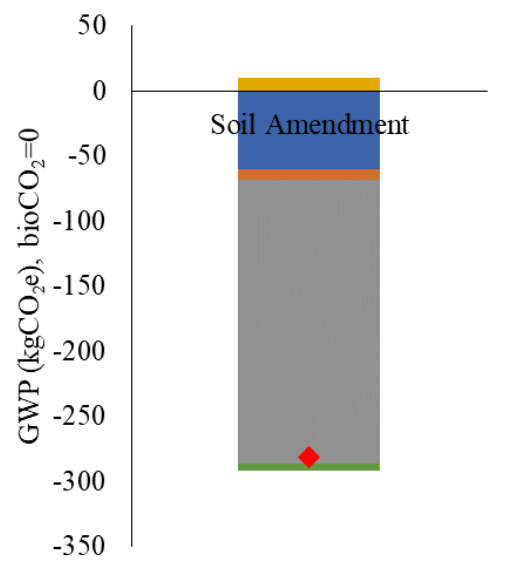

n Other

- Dinitrogen monoxide

- Carbon dioxide, fossil

Methane, non-fossi]

- Carbon dioxide, storage

- Total
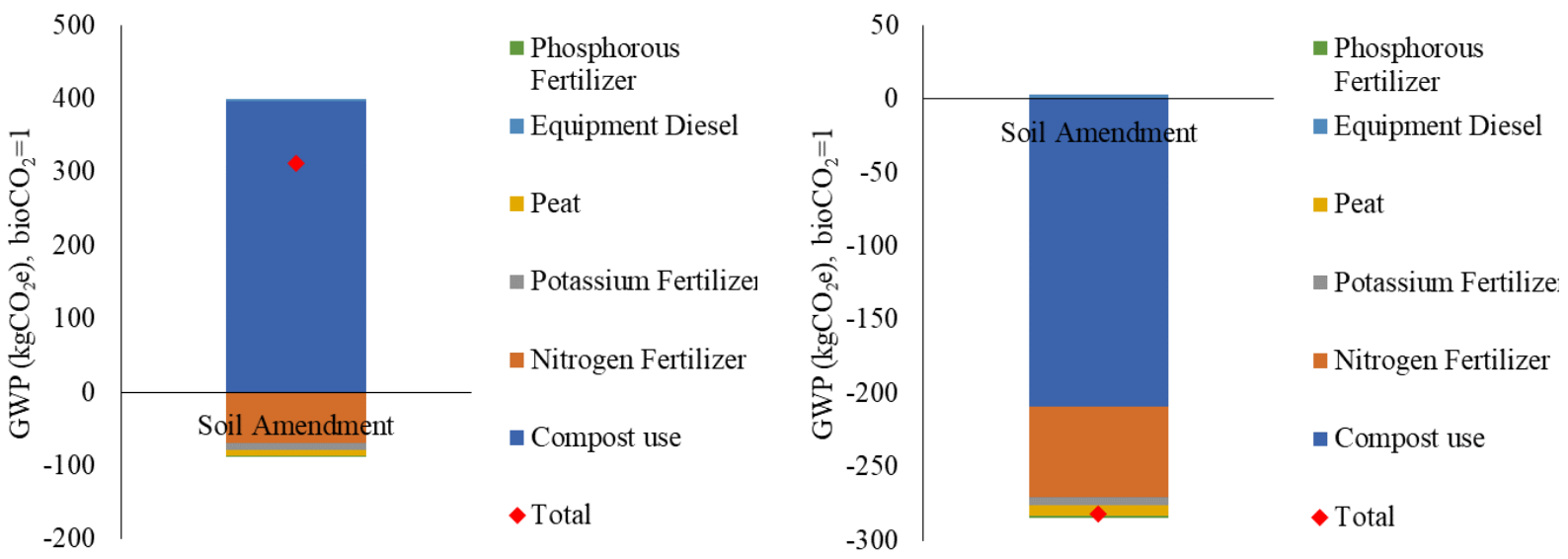

Figure S17. Breakdown of top emissions (top figures) and activities (bottom figures) that contribute to GWP of the soil amendment scenario according to the IPCC 2013 and assumptions that biogenic $\mathrm{CO}_{2}$ emissions are neutral (left figures) or equal to fossil $\mathrm{CO}_{2}$ emissions (right figures). 


\section{REFERENCES}

(1) Boldrin, A.; Hartling, K. R.; Laugen, M.; Christensen, T. H. Environmental Inventory Modelling of the Use of Compost and Peat in Growth Media Preparation. Resour. Conserv. Recycl. 2010, 54 (12), 1250-1260. https://doi.org/10.1016/J.RESCONREC.2010.04.003.

(2) Boldrin, A.; Andersen, J. K.; Møller, J.; Christensen, T. H.; Favoino, E. Composting and Compost Utilization: Accounting of Greenhouse Gases and Global Warming Contributions. Waste Manag. Res. 2009, 27 (8), 800-812. https://doi.org/10.1177/0734242X09345275.

(3) Solid Waste Technology \&amp; Management; Christensen, T. H., Ed.; John Wiley \& Sons, Ltd: Chichester, UK, 2010. https://doi.org/10.1002/9780470666883.

(4) Myhre, G.; Shindell, D.; Bréon, F.-M.; Collins, W.; Fuglestvedt, J.; Huang, J.; Koch, D.; Lamarque, J.-F.; Lee, D.; Mendoza, B.; Nakajima, T.; Robock, A.; Stephens, G.; Takemura, T.; Zhang, H. Anthropogenic and Natural Radiative Forcing. In Climate Change 2013 the Physical Science Basis: Working Group I Contribution to the Fifth Assessment Report of the Intergovernmental Panel on Climate Change; Cambridge University Press: Cambridge, United Kingdom and New York, NY, USA., 2013; Vol. 9781107057, pp 659-740. https://doi.org/10.1017/CBO9781107415324.018.

(5) Forster, P.; Ramaswamy, V.; Artaxo, P.; Berntsen, T.; Betts, R.; Fahey, D. W.; Haywood, J.; Lean, J.; Lowe, D. C.; Myhre, G.; Nganga, J.; Prinn, R.; Raga, G.; Schulz, M.; Dorland, R.V. Changes in Atmospheric Constituents and in Radiative Forcing. In Climate Change 2007: The Physical Science Basis. Contribution of Working Group I to the Fourth Assessment Report of the Intergovernmental Panel on Climate Change; Cambridge University Press: Cambridge, United Kingdom and New York, NY, USA, 2007.

(6) Levis, J. W.; Barlaz, M. A. Anaerobic Digestion Process Model Documentation; Raleigh, NC, 2013. http://go.ncsu.edu/swolf_ad

(7) Levis, J. W.; Barlaz, M. A. Composting Process Model Documentation; Raleigh, NC, 2013. http://go.ncsu.edu/swolf_composting

(8) Staley, B. F.; Barlaz, M. A. Composition of Municipal Solid Waste in the United States and Implications for Carbon Sequestration and Methane Yield. J. Environ. Eng. 2009, 135 (10), 901-909. https://doi.org/10.1061/(ASCE)EE.1943-7870.0000032.

(9) García, R.; Pizarro, C.; Lavín, A. G.; Bueno, J. L. Spanish Biofuels Heating Value Estimation. Part II: Proximate Analysis Data. Fuel 2014, 117 (PARTB), 1139-1147. https://doi.org/10.1016/j.fuel.2013.08.049.

(10) Meraz, L.; Domínguez, A.; Kornhauser, I.; Rojas, F. A Thermochemical Concept-Based Equation to Estimate Waste Combustion Enthalpy from Elemental Composition. Fuel 2003, 82 (12), 1499-1507. https://doi.org/10.1016/S0016-2361(03)00075-9.

(11) Hla, S. S.; Roberts, D. Characterisation of Chemical Composition and Energy Content of Green Waste and Municipal Solid Waste from Greater Brisbane, Australia. Waste Manag. 2015, 41, 12-19. https://doi.org/10.1016/j.wasman.2015.03.039. 
(12) US EPA. Advancing Sustainable Materials Management: 2017 Fact Sheet; Washington, D.C., 2019.

(13) Jaunich, M. K.; Levis, J. W.; DeCarolis, J. F.; Barlaz, M. A.; Ranjithan, S. R. Solid Waste Management Policy Implications on Waste Process Choices and Systemwide Cost and Greenhouse Gas Performance. Environ. Sci. Technol. 2019, 53 (4), 1766-1775. https://doi.org/10.1021/acs.est.8b04589.

(14) Levis, J.; Barlaz, M. A. Landfill Gas Monte Carlo Model Documentation and Results; Washington, D.C., 2014. https://go.ncsu.edu/lf_warm 